INTERNATIONAL JOURNAL OF ORGANIC EVOLUTION

P U B L I S H E D B Y

THE SOCIETY FOR THE STUDY OF EVOLUTION

\begin{tabular}{lll}
\hline Vol. 36 & July, 1982 & No. 4
\end{tabular}

Evolution, 36(4), 1982, pp. $637-657$

\title{
NICHE SHIFTS AND COMPETITION IN DARWIN'S FINCHES: GEOSPIZA CONIROSTRIS AND CONGENERS
}

\author{
B. R. Grant and P. R. GRant \\ Division of Biological Sciences, University of Michigan, Ann Arbor, Michigan 48109
}

Received February 5, 1981. Revised October 20, 1981

The idea that interspecific competition is an important process in structuring communities stems largely from David Lack's work with Darwin's Finches (Lack, 1940, 1945, 1947, 1969). Lack made ecological inferences about feeding niches from analyses of bill sizes and shapes. $\mathrm{He}$ listed several instances where the niches of coexisting species were different, and where the niche of an absent species appeared to be occupied by one or more species present. These examples he interpreted as evidence of competitive displacement and exclusion.

Lack's aim was to offer a coherent theoretical framework for understanding the adaptive radiation of Darwin's Finches, not to test specific hypotheses. In contrast, our aim is to test the hypothesis of interspecific competition. This is needed because the evidence in general for interspecific competition as an important factor in determining niche relationships and community patterns has been critically debated recently (e.g., Connell, 1975, 1978, 1980; Wiens, 1977; Connor and Simberloff, 1978, 1979; Simberloff, 1978; Strong et al., 1979; Abbott, 1980; Grant and Abbott, 1980; Ricklefs and Travis, 1980; Rotenberry and Wiens, 1980; Wiens and Rotenberry, 1980). We can return to Darwin's Finches to perform such tests without circularity by obtaining and applying quan- titative ecological data to the hypotheses, because quantitative data were not used to construct the hypotheses. In fact, Lack had almost no ecological data (see Abbott et al., 1977).

In our initial studies we analyzed ecological and morphological data from six species on eight Galápagos islands (Abbott et al., 1977; Smith et al., 1978). To follow this general approach, we selected for more detailed study three situations which have been heralded as especially clear illustrations of competitive effects (e.g., Lack, 1969; Williamson, 1972; Arms and Camp, 1979), the small size of Geospiza fortis on Isla Daphne Major in the absence of $G$. fuliginosa (Boag, 1981), mutually exclusive distributions of $G$. fuliginos $a$ and $G$. difficilis (Schluter and Grant, unpubl.), and differences in bill size between populations of $G$. conirostris. Here we report the results of the third study in which we test the hypothesis of competition between $G$. conirostris and congeneric species.

\section{The Interspecific Competition Hypothesis Applied to \\ G. conirostris}

Geospiza conirostris occurs on Isla Española (Hood) and its satellite Gardner in the south of the archipelago, and on Isla Genovesa (Tower) in the northeast (Fig. 1). It has been recorded also on Islas Pinta 


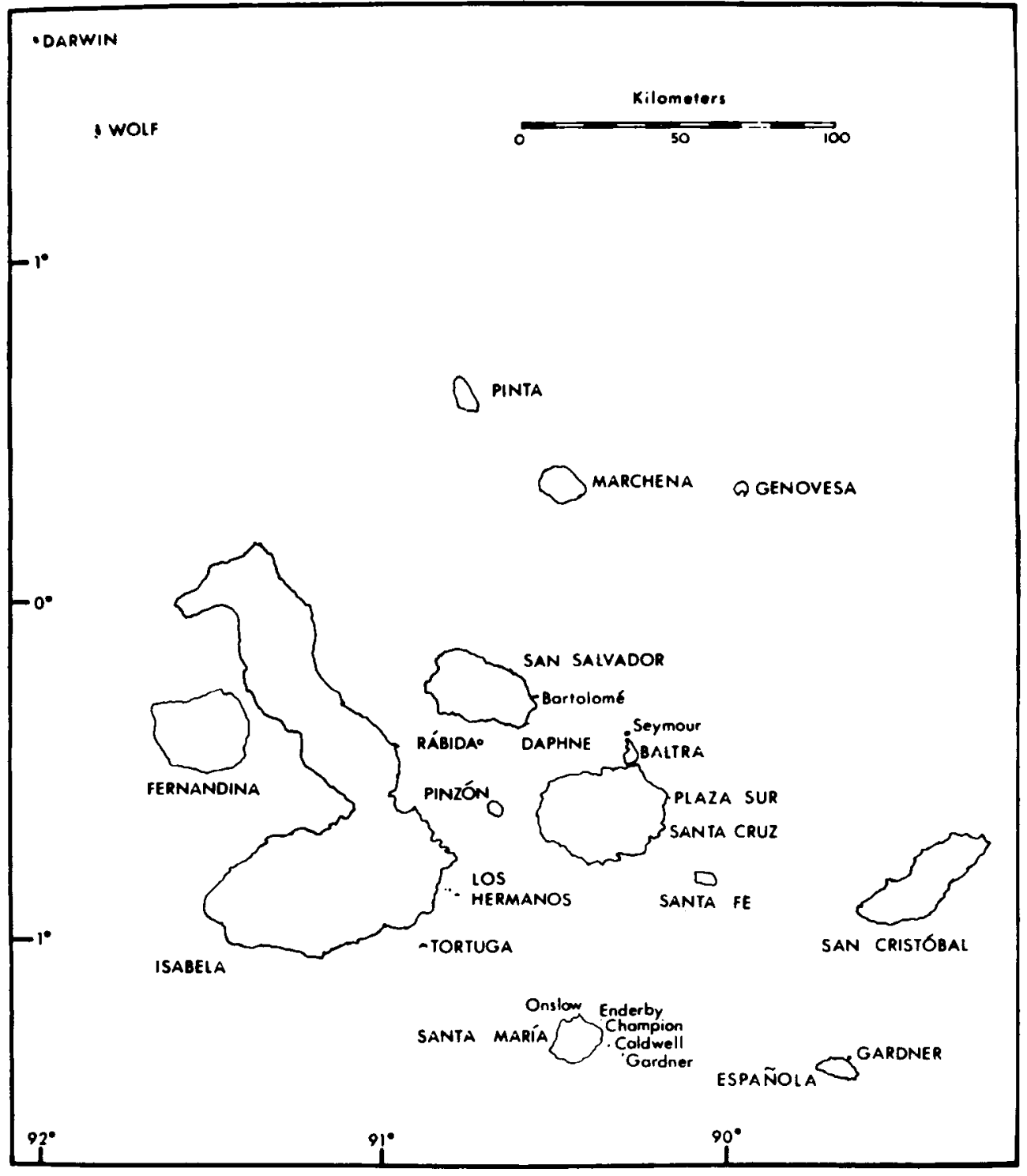

FrG. 1. The Galápagos Islands.

(Abingdon), Wolf (Wenman) and Darwin (Culpepper), but has not been seen on these three islands recently (Harris, 1973; Bowman, 1979, and pers. comm.; D. Schluter, pers. comm.), so these latter three islands will be ignored.

Lack $(1945,1947)$ argued from the beak shapes of conirostris on Española and Genovesa that the niche on Española is a composite of the niches of absent G. mag- nirostris, G. fortis and G. scandens, and that the niche on Genovesa, in the presence of magnirostris, is a composite of the niches of absent fortis and scandens (Fig. 2). According to this argument, the interisland difference in the niche of conirostris is attributable to just one variable identified, namely the competitive influence of magnirostris. A competitive displacement between conirostris and magnirostris is 


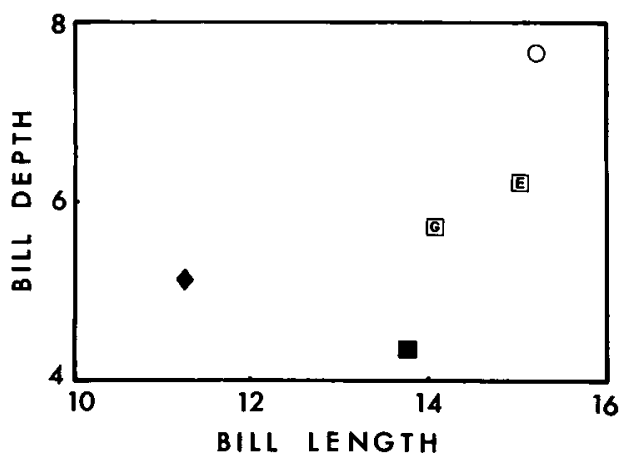

FIG. 2. Average beak size in millimeters of four finch species: Geospiza fortis ( ) from I. Daphne, $G$. scandens ( $\square$ ) from I. Daphne, G. magnirostris (O) from I. Genovesa and $G$. conirostris $(\square)$ from $I$. Genovesa (G) and I. Española (E).

also implied. Lack (1969) also proposed that conirostris has competitively excluded magnirostris, fortis and possibly scandens from Española, and that fortis and scandens have been competitively excluded from Genovesa by conirostris and/or magnirostris. The three species which apparently have been excluded by conirostris are widely distributed throughout the archipelago on almost all the major islands, including those nearest to Española and Genovesa. However magnirostris has become extinct on Sta. María and S. Cristóbal (see Fig. 1) since Darwin's visit to the archipelago in 1835 (Sulloway, 1982).

\section{Tests of the Competition Hypothesis}

Testing the hypothesis is difficult for two reasons. The first is that it deals with events in the past. Historical processes cannot be tested directly in the way that contemporary processes can, except in the unlikely circumstances that the reactants are brought together under the same conditions as prevailed in the past. Instead, the hypothesis can be tested through its consequences (predictions). The assumptions upon which it rests may also be tested, and if they are shown to be wrong they must be replaced or the hypothesis must be discarded in favor of another.

The second difficulty is that Lack's argument was neither entirely explicit nor presented in the form in which it was constructed. In his book Lack (1947) first presented his facts, then followed them with an interpretation. But Richards (1948) pointed out that there was almost as much interpretation in the presentation of facts as in the section devoted to interpretation: "It is impossible to collect or arrange scientific data without some theory which automatically introduces an element of interpretation" (Richards, 1948 p. 83). To put Lack's argument into a testable framework we must rephrase it. His observations to be explained were the distribution of species and inter-island differences in beak shape; his hypothesis was that distribution and morphology were causally influenced by interspecific competition for food; and his main assumption was that the feeding niche of a population was reflected in the average beak characteristics.

The above assumption and the corollary that diet differences parallel beak differences have been supported by the results of recent work with several species of Darwin's Finches (Abbott et al., 1977; Grant et al., 1976; Smith et al., 1978; Grant and Grant, 1979; Grant and Grant, 1980a; Grant, 1981). Therefore we might expect that conirostris on Española, with mean beak characteristics intermediate between those of the absent magnirostris, fortis and scandens (Fig. 2), has an intermediate feeding niche position too. However niche breadth and overlap are functions of niche size and shape as well as position (Pianka, 1969; Colwell and Futuyma, 1971; Colwell, 1979). Therefore an intermediate feeding niche position does not necessarily mean that the feeding niche of conirostris combines the niches of the three missing species or that the conirostris niche is particularly broad. For this reason we regard Lack's statements about niche similarities, differences and breadths to be testable, i.e., falsifiable predictions of the competition hypothesis. For example, if we found that conirostris on Española did not feed in a manner exhibited by magnirostris, fortis and scandens elsewhere, we would consider the competition hypothesis, as it is applied to the absence of these three 
species, to be falsified by the failure of the prediction.

It is also predicted from the competition hypothesis that missing species would be less efficient than the species present in locating and dealing with the foods on a particular island if these missing species were to arrive. Lack (1969) used this argument when invoking the competitive exclusion hypothesis to argue for the competitive superiority of conirostris on Genovesa and Española, but inferiority elsewhere. We consider this to be another prediction of the hypothesis that can be tested by comparing the feeding efficiency of different species on the same species of seeds.

There are alternative explanations to the competition hypothesis for the absence of fortis and scandens from both islands and magnirostris from Española. One is that their food niches are not present on these islands (Bowman, 1961). We will examine this possibility when testing the niche expansion predictions. Other explanations are that they have been unable to reach the islands, and that they may have arrived in small numbers but, not finding mates of their own species, hybridized with the resident birds. We will consider these possibilities in the Discussion.

\section{Methods}

Food supply and feeding habits of the finches vary seasonally (Smith et al., 1978; Grant and Grant, 1980a). To make meaningful inter-island comparisons we restrict our attention to data collected in the months June to August, i.e., the first half of the dry (non-breeding) season: I. Española, 8-25 August 1979, supplemented with data collected 26 May-5 June 1973 (Abbott et al., 1977); I. Genovesa, 23 June-4 August 1979; I. Daphne (no conirostris) 21 June-7 July 1975 . We chose the early and middle dry season because beak adaptations are clearly seen then (Grant and Grant 1980a, Smith et al., 1978). Later in the dry season, i.e., from October and November onwards, Opuntia cactus comes into flower and all four species feed intensively on the pollen and nectar (Grant and Grant, 1980a, 1980b; Grant and Grant, 1981). Our random sampling of seeds and fruits on the ground and on bushes, method of measuring them, and our systematic recording of feeding behavior and diets have been described in Abbott et al. (1977) and Smith et al. (1978). The only difference is that the study grid on Española was changed from the area in 1973 to one $500 \mathrm{~m}$ south that contained Opuntia megasperma trees. We did this in order to have Opuntia in both study areas on Española and Genovesa where feeding observations were made.

\section{RESULTS \\ Prediction of Niche Expansion on I. Española}

To test the prediction of the competition hypothesis that the feeding niche of conirostris on Española combines the feeding niche of magnirostris, fortis and scandens, we first ask if conirostris feeds on the same food items taken by magnirostris, fortis and scandens on other islands.

Table 2 lists the plant species present on Española that are used for food by $G$. conirostris there, and by finches elsewhere in the archipelago. This table shows that many of the seeds eaten by $G$. conirostris are eaten by magnirostris, fortis and scandens on other islands. With the exception of Sida spinosa and Alternanthera echinocephala (Table 2), the seeds on Española which are not taken by conirostris but which are taken by other finch species on other islands are rare, either for natural reasons or because the plants have been largely removed by introduced goats as in the case of Croton scouleri. Seeds of the two exceptional species are very small and soft, they do not form an important part of the diets of fortis and scandens elsewhere, and they are not eaten by magnirostris elsewhere. Therefore conirostris on Española do feed on the same food items taken by magnirostris, fortis and scandens elsewhere.

A more difficult question to answer is whether a sufficient supply of seeds is available on Española for the subsistence 
TABLE 1. Ground finches present on Islas Española, Daphne and Genovesa; the mean weights in grams and bill dimensions in millimeters ( \pm one standard error) of adult males, with sample sizes in parentheses. * = measurements of live birds; all other measurements were taken from museum specimens by I. Abbott.

\begin{tabular}{|c|c|c|c|c|c|}
\hline Island & Finch species & Weight & $\begin{array}{l}\text { Upper mandible } \\
\text { length }\end{array}$ & $\begin{array}{c}\text { Upper mandible } \\
\text { depth }\end{array}$ & $\begin{array}{c}\text { Lower mandible } \\
\text { width }\end{array}$ \\
\hline Española & $\begin{array}{l}\text { G. conirostris } \\
G . \text { fuliginosa }\end{array}$ & $\begin{array}{l}35.8 \pm 0.8^{*}(26) \\
13.8 \pm 0.3^{*}(7)\end{array}$ & $\begin{aligned} 15.0 & \pm 0.1 \\
8.4 & \pm 0.1\end{aligned}$ & $\begin{array}{ll}6.2 \pm 0.1 & (120) \\
3.6 \pm 0.1 & (37)\end{array}$ & $\begin{aligned} 11.7 \pm 0.1 & (119) \\
6.6 \pm 0.1 & (36)\end{aligned}$ \\
\hline Daphne & $\begin{array}{l}G . \text { scandens } \\
G . \text { fortis }\end{array}$ & $\begin{array}{l}22.0 \pm 0.4^{*}(23) \\
17.5 \pm 0.4 *(27) \\
\end{array}$ & $\begin{array}{l}14.9 \pm 0.1^{*}(22) \\
10.3 \pm 0.1\end{array}$ & $\begin{array}{l}4.7 \pm 0.1 *(10) \\
4.4 \pm 0.1 \quad(31)\end{array}$ & $\begin{array}{l}8.9 \pm 0.1^{*}(23) \\
8.2 \pm 0.1\end{array}$ \\
\hline Genovesa & $\begin{array}{l}\text { G. magnirostris } \\
G . \text { conirostris } \\
G . \text { difficilis }\end{array}$ & $\begin{array}{l}36.0 \pm 0.8^{*}(26) \\
25.3 \pm 0.4^{*}(24) \\
11.5 \pm 0.1^{*}(50)\end{array}$ & $\begin{array}{r}16.1 \pm 0.2 \\
14.1 \pm 0.1 \quad(38) \\
9.1 \pm 0.1\end{array}$ & $\begin{array}{l}7.7 \pm 0.2 \\
5.7 \pm 0.1 \\
3.3 \pm 0.0\end{array}$ & $\begin{array}{r}15.9 \pm 0.1 \\
9.8 \pm 0.1 \\
6.2 \pm 0.0 \quad(85) \\
\end{array}$ \\
\hline
\end{tabular}

TABLE 2. Plant species present on Española that have seeds eaten by finches on Española and other islands in the archipelago. Percent coverage is given on the basis of 50 random quadrats at each site. (Depth $\times$ Hardness) $)^{2}$ values for seeds and percentage coverage of plants are taken from Abbott et al., 1977 and supplemented with our own data. Symbols: $X=$ present on island; seeds eaten by $M=\mathrm{G}$. magnirostris, $C=\mathrm{G}$. conirostris on Española, $C g=\mathrm{G}$. conirostris on Genovesa, $F=\mathrm{G}$. fortis, $S=\mathrm{G}$. scandens, $F u l=\mathrm{G}$. fuliginosa. Double underlining $=\geqslant 5 \%$ of feeding time spent on this food item at any one time of the year.

\begin{tabular}{|c|c|c|c|c|}
\hline \multirow[b]{2}{*}{ Plant species on Española } & \multirow[b]{2}{*}{$(\mathrm{DH})^{1 / 2}$ of seeds } & \multirow[b]{2}{*}{$\begin{array}{c}\text { Percent } \\
\text { occurrence }\end{array}$} & \multicolumn{2}{|c|}{ Seeds eaten } \\
\hline & & & $\begin{array}{c}\text { By finches } \\
\text { on Española }\end{array}$ & $\begin{array}{c}\text { By finches } \\
\text { on other islands }\end{array}$ \\
\hline Cordia lutea & $13-14$ & 34 & $\underline{\mathrm{C}}$ & $\underline{\underline{\mathbf{M}}}$ \\
\hline Opuntia megasperma & $10-11$ & $\mathrm{X}$ & $\mathbf{C}$ & \\
\hline Prosopis juliflora & $10-11$ & 50 & $\underline{\mathrm{C}}$ & $\underline{\mathbf{M}}$ \\
\hline Tribulus cistoides & $9-10$ & $\mathbf{x}$ & $\underline{\underline{C}}$ & $\underline{\underline{M}, \mathbf{F}}$ \\
\hline Bursera graveolens & $4-6$ & $\mathbf{X}$ & $\mathrm{C}$ & $\underline{\underline{\mathbf{M}}, \mathbf{F}, \mathrm{S}, \mathrm{Cg}}$ \\
\hline Ipomoea triloba & $3-4$ & $\mathbf{X}$ & $\mathrm{C}$ & $\mathbf{M}, \mathbf{F}, \mathbf{C g}$ \\
\hline Neptuna plena & $3-4$ & $\mathbf{X}$ & C & $\underline{\underline{M}}$ \\
\hline Cenchrus platyacantus & $3-4$ & 2 & $\underline{\underline{C}}$ & $\overline{\mathbf{M}}, \underline{\mathbf{F}}, \mathrm{S}$ \\
\hline Rhynchosia minima & $3-4$ & 4 & & $\underline{\mathbf{F}}$ \\
\hline Vallesia glabra & $2-3$ & $\mathbf{x}$ & $\mathrm{C}$ & $\mathbf{F}$ \\
\hline Grabowskia boerhaavifolia & $2-3$ & $\mathbf{X}$ & & $\mathbf{F}, \mathbf{S}$ \\
\hline Lantana peduncularis & $2-3$ & 14 & $\underline{\mathrm{C}}$, Ful & $\mathbf{M}, \underline{\underline{F}}, \mathbf{C g}$ \\
\hline Desmanthus virgatus & $2-3$ & 8 & C & \\
\hline $\begin{array}{l}\text { Tribulus cistoides } \\
\quad \text { (unripe fruit on plant) }\end{array}$ & $2-3$ & $\mathrm{X}$ & C & $\underline{\mathbf{F}}, \mathrm{S}$ \\
\hline Trianthema portulacastrum & $1-2$ & 16 & $\overline{\mathrm{C}}, \mathrm{Ful}$ & \\
\hline Chamaesyce recurva & $1-2$ & 2 & & $\mathrm{~F}, \mathrm{Cg}$ \\
\hline Croton scouleri & $1-2$ & $\mathbf{X}$ & & $\underline{\underline{\mathrm{M}}, \mathrm{F}}, \mathrm{Cg}$ \\
\hline Abutilon depauperatum & $1-2$ & 4 & & $\mathbf{M}$ \\
\hline Boerhaavia erecta & $0-1$ & 2 & C, Ful & $\mathbf{F}$ \\
\hline Cryptocarpus pyrformis & $0-1$ & $\mathbf{x}$ & Ful & \\
\hline Aristida subpicata & $0-1$ & $\mathbf{X}$ & $\mathrm{C}, \mathrm{Ful}$ & $\mathbf{F}, \underline{\underline{S}}$ \\
\hline Panicum fasiculatum & $0-1$ & 22 & $\underline{\underline{C}}$, Ful & $F, \underline{\underline{S}}$ \\
\hline Sida spinosa & $0-1$ & 18 & & $\mathbf{F}$ \\
\hline Alternanthra echinocephala & $0-1$ & 20 & & $\mathbf{F}, \mathrm{S}$ \\
\hline
\end{tabular}


TABLE 3. Plant species present on Genovesa that have seeds eaten by finches either on Genovesa or other islands in the archipelago. Symbols as in Table 2: $D=\mathrm{G}$. difficilis.

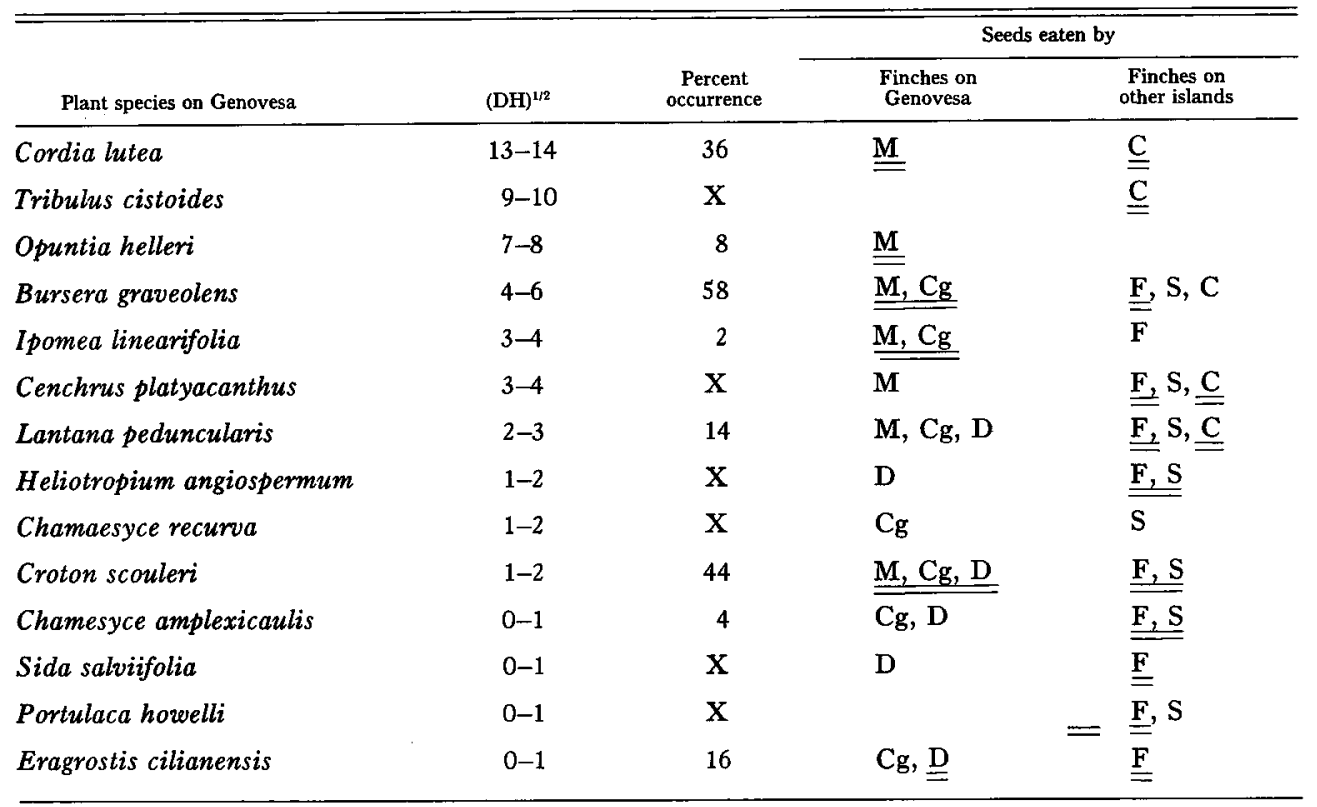

of populations of magnirostris, fortis and scandens. The answer is clearest with magnirostris. In the dry season on I. Genovesa magnirostris feed almost entirely on the seeds of two species, Cordia lutea and Opuntia helleri (Smith et al., 1978; Grant and Grant, 1980a). Cordia lutea occurs about as frequently on Española as on Genovesa (Table 3). Opuntia helleri is more common on Genovesa than $O$. megasperma is on Española, and the seeds of $O$. helleri are smaller and softer than the seeds of $O$. megasperma (Tables 2 and 3). Opuntia helleri is distributed throughout Genovesa at approximately the same frequency as in the study grid (Table 3), whereas on Española $O$. megasperma is patchily distributed. However it is doubtful if the relative scarcity of Opuntia and hardness of the seeds are factors responsible for the absence of magnirostris on Espanola. First, in our five visits to Genovesa during the dry season Cordia seeds were more important in the diet of magnirostris than Opuntia seeds (Grant and Grant, 1980a). Second, the large O. megasperma seeds are well within the cracking range of magnirostris (Table 2, also see below). Therefore the abundant supply of Cordia lutea seeds and the sparse supply of $O$. megasperma seeds on Española should be sufficient to sustain a population of magnirostris in dry seasons. In addition there are other large hard seeds such as Prosopis juliflora which occur abundantly throughout Española (Table 2), and although they are absent from Genovesa, they constitute a major proportion of magnirostris diets in the coastal areas of Isla Pinta (D. Schluter, pers. comm.).

Geospiza fortis subsists on a variety of small seeds in the dry season on I. Daphne prior to Opuntia flowering (Grant and Grant, 1980b). Those seeds, or close relatives, are present on Española (Table 2; see also Abbott et al., 1977). In particularly dry years on Daphne some fortis add the moderately hard Tribulus cistoides to their diet (Grant and Grant, 1980b). Tribulus cistoides is also present on Española. There is inevitable uncertainty about whether the Tribulus seeds are sufficiently common to sustain a population of fortis in the middle-late dry season in a dry year, and whether Opuntia flowers are sufficiently common at the end of the dry sea- 
TABLE 4. Proportion of foraging time spent on food items and feeding activities in the early dry season. Opuntia was not flowering in July and August on Española and Daphne. *Two individuals seen to crack $\mathrm{O}$. helleri seeds.

\begin{tabular}{|c|c|c|c|c|c|}
\hline & $\begin{array}{c}\text { August } 1979 \\
\text { Española } \\
\text { G. conirostris }\end{array}$ & $\begin{array}{l}\text { July } 1975 \\
\text { Daphne } \\
\text { G. fortis }\end{array}$ & $\begin{array}{c}\text { July } 1975 \\
\text { Daphne } \\
\text { G. scandens }\end{array}$ & $\begin{array}{c}\text { July } 1979 \\
\text { Genovesa } \\
\text { G. magnirostris }\end{array}$ & $\begin{array}{c}\text { July } 1979 \\
\text { Genovesa } \\
\text { G. conirostris }\end{array}$ \\
\hline Small seeds on ground & .291 & .464 & .490 & .087 & .197 \\
\hline Seeds $(\mathrm{DH})^{\frac{1}{2}} 0-1$ & & .272 & .039 & & .012 \\
\hline $1-2$ & .002 & .004 & .010 & & .029 \\
\hline $2-3$ & .064 & .034 & .191 & & \\
\hline $4-6$ & & .023 & .001 & .006 & \\
\hline $7-14$ & .295 & & & .861 & $.011^{*}$ \\
\hline Tribulus mericarp fragments & + & .142 & .057 & & \\
\hline Opuntia flower & & & & & .025 \\
\hline Opuntia aril & .040 & .034 & .191 & .045 & .495 \\
\hline $\begin{array}{l}\text { Opuntia pad ripping } \\
\text { and probing for arthropods }\end{array}$ & .280 & .020 & .005 & & 036 \\
\hline Opuntia spine base & .001 & .001 & .009 & & \\
\hline Bark ripping & .027 & & & & .157 \\
\hline Gleaning & & & .005 & & .039 \\
\hline Sulidae egg & & .006 & .004 & .001 & \\
\hline Total seconds & 26,135 & 20,266 & 5,285 & 12,255 & 19,416 \\
\hline
\end{tabular}

son. But given the large range of alternative foods for fortis on Española, we conclude that a population of fortis could be sustained there.

Geospiza scandens feeds on small seeds and cactus products. In years such as 1975, when there is abundant rainfall during the wet season, small seeds are plentiful in the dry season and these are taken from plants and from the ground (Table 4). Geospiza scandens then turns to Opuntia pollen and nectar when flowers start blooming in October (Smith et al., 1978; Grant and Grant, $1980 b$ ). In the dry season in dry years on Daphne it feeds largely on Opuntia echios seeds and arils; for example, the proportion of time spent foraging on these items was .900 in August of 1980, a relatively dry year. On Española the large and hard seeds of Opuntia megasperma are certainly beyond the cracking power of scandens, and the aril is fibrous and less rewarding than the succulent arils of Opuntia seeds elsewhere. Despite these observations, a scandens population could be self-sustaining on Española through a diet of small seeds and insect larvae taken from Opuntia pads, because on Isla Marchena, where Opuntia helleri reproduces mainly vege- tatively and flower production and seed set are low, $G$. scandens feeds mainly on diptera larvae extracted from rotting Opuntia pads in the dry season (D. Schluter, pers. comm.). On Isla Champion off Floreana, Opuntia megasperma var. megasperma is abundant, and like $O$. megasperma var. orientalis on Española, the aril is fibrous, but the seeds are even harder. In August 1980 we recorded $G$. scandens feeding for proportionately $56.8 \%$ of its foraging time on beetle larvae and pupae from rotting Opuntia pads (see also Table 4 for data from Daphne). We found many beetle larvae and pupae in Opuntia pads on Española.

Not one of the three species, magnirostris, fortis or scandens, is dependent upon one or more food types that are lacking on Española, and several of their diet items are present. The evidence contradicts the hypothesis that the three species are absent because suitable foods are lacking.

\section{The Prediction of Niche Expansion on I. Genovesa}

To test the prediction that the feeding niche of conirostris on Genovesa combines the feeding niche of fortis and scan- 
dens we follow the same argument concerning missing species on Española. That is, we first ask if Genovesa conirostris feed on the same food items as missing fortis and scandens do on other islands. Table 3 lists the plant species on Genovesa and the diets of present and absent finch species. It shows that many food items or else close relatives present on Genovesa which are consumed by conirostris are eaten by fortis and scandens on other islands.

The question of whether there is sufficient food on Genovesa to support a population of fortis and scandens can be answered with a similar argument to the one presented above concerning the absence of fortis and scandens on Española. Plants are widely distributed throughout Genovesa (Grant and Grant, 1980a) at approximately the same frequency as in the study grid (Table 3). Many small seeds present and common on Genovesa are consumed by fortis and scandens elsewhere (Table 3). Although $O$. helleri seeds are hard and beyond the cracking powers of fortis and scandens, the aril is fleshy and succulent and similar to the aril of $O$. echios which is eaten by fortis and scandens on Daphne (Table 4). Opuntia helleri is abundant and flowers bloom profusely from November to May (Grant and Grant, $1980 a$ ) and would provide pollen and nectar for both species. Rotting Opuntia pads contain diptera larvae. Thus a diet of small seeds, Opuntia arils and pollen would be available for fortis on Genovesa. This is similar to the diet of fortis on Daphne. If scandens can subsist on Marchena and Champion on dry season diets of small seeds and arthropod larvae taken from Opuntia pads, they could surely survive on Genovesa where in addition to a supply of small seeds Opuntia is common and would provide arils, diptera larvae, pollen and nectar. Therefore many food items present on Genovesa are consumed by fortis and scandens elsewhere, and there are no known essential constituents missing. So there is no reason to suppose fortis and scandens are absent from Genovesa because their foods are not present.
We have found that the range and abundance of food plants present on Española and Genovesa should be sufficient to support populations of fortis and scandens on both islands and magnirostris on Española. We now ask if conirostris feeding niches combine the feeding niches of the missing species and answer this by comparing the feeding niches of conirostris with the feeding niches of the missing species on other islands in a similarity analysis.

\section{Comparison of Allopatric Feeding Niches}

Table 4 shows the proportion of feeding time spent on various food items in July and August. Several parts of Opuntia as well as seeds are a source of food for the finches, particularly scandens and conirostris. Therefore Opuntia feeding must be considered, together with seed consumption, in a comparison of feeding niches. Seeds have been grouped into depth-hardness classes for comparative purposes, except that the mericarps (fruit parts) of Tribulus cistoides have been considered separately because of the unique problems they pose to birds (Grant, 1981a). The result is a classification of proportional feeding in 14 categories. Grouping seeds into a few size categories could bias the results in favor of greater similarity. We believe that bias is minimal because many of the seeds within one category are from the same plant species on different islands. Where they are not, all the seed species within the category are eaten by both species being compared on at least one island in the archipelago. For example, seed size-hardness category 7-14 includes Opuntia helleri and Cordia lutea on Genovesa, and Opuntia megasperma, Prosopis juliflora and Cordia lutea on Española. Geospiza magnirostris eats $O$. helleri and C. lutea seeds on Genovesa and Prosopis juliflora on Pinta. Geospiza conirostris takes all three species on Española.

To compare feeding niches we use the index of similarity $1-0.5\left(\Sigma\left|p_{1 i}-p_{2 i}\right|\right)$ where $p_{1 i}$ and $p_{2 i}$ are the proportions of foraging time spent by the two species on 
TABLE 5. Similarities in the foraging of pairs of Geospiza species observed over 8-day periods.

\begin{tabular}{lll}
\hline \hline Española G. conirostris & v Genovesa $G$. conirostris & SIM $=.31$ \\
& v Daphne $G$. fortis & SIM $=.38$ \\
& v Daphne $G$. scandens & SIM $=.40$ \\
& v Genovesa $G$. magnirostris & SIM $=.42$ \\
& v Española $G$. fuliginosa & SIM $=.37$ \\
& v G. magnirostris and conirostris & SIM $=.53$ \\
& v G. scandens and fortis & SIM $=.41$ \\
& v G. magnirostris, fortis and scandens & SIM $=.65$ \\
Genovesa G. conirostris & v Genovesa $G$. magnirostris & SIM $=.14$ \\
& v Daphne $G$. fortis & SIM $=.27$ \\
& v Daphne $G$. scandens & SIM $=.42$ \\
& v G. fortis + scandens & SIM $=.30$ \\
\hline
\end{tabular}

food items classified in Table 4. This is appropriate for discrete classes of food items not measured along a common scale (Whittaker, 1960). We do not have comparable estimates of nectar, pollen, aril, arthropod and seed density; therefore we are unable to use Hurlbert's (1978) method of comparing diet similarity in relation to food availability. Table 5 gives the similarities based on the combined observations of eight successive days. There are no confidence limit estimates on the similarity values, but the values are not close to 0 and 1 where sampling distortions are likely to be greatest (Ricklefs and Lau, 1980). Figure 3 shows cumulative similarities over a period of eight successive days. The stability of the similarities after about five days suggests that our results would not have been very different if we had extended the period of observation.

Española conirostris is closest in feeding habits to magnirostris (similarity $=.42$ ). This results from both species taking large and hard seeds. The difference is due to Espanola conirostris also taking small seeds and ripping open Opuintia pads to feed on dipteran larvae and pupae. In this respect Española conirostris resemble fortis and scandens. And in fact, in agreement with the prediction of the competition hypothesis, the feeding niche of Española conirostris is more similar to an unweighted composite of magnirostris, fortis and scandens niches on other islands than it is to the niches of these three species treated separately, to the niche of conspecific conirostris population on Genovesa, or to any pairwise combinations of niches of these species (Table 5). Furthermore Española conirostris has the greatest niche breadth (Table 6).

The competition hypothesis also predicts that the feeding niche of Genovesa conirostris is more similar to the composite niche of fortis and scandens than to the niches of these two considered separately or to the niche of the conirostris population on Española. This prediction is not fully realized (Table 5). The niche of Genovesa conirostris is most similar to the niche of scandens considered alone. The composite niche of scandens and fortis, the niche of fortis alone and the niche of Española conirostris are all about equally similar to the niche of Genovesa conirostris. Reference to Table 4 will show the reasons for these results. Genovesa conirostris is similar to scandens because both exploit Opuntia, but conirostris spends more time ripping the bark off Bursera and Croton branches to get at arthropods, mainly termites, and less time feeding on small seeds on the ground than scandens does. The similarity between conirostris and fortis is lower because fortis exploits Opuntia parts less and small seeds on the ground more than both scandens and conirostris.

Thus the evidence shows that the conirostris niche on Genovesa is similar to the scandens niche but does not support the prediction that it is similar to a composite 

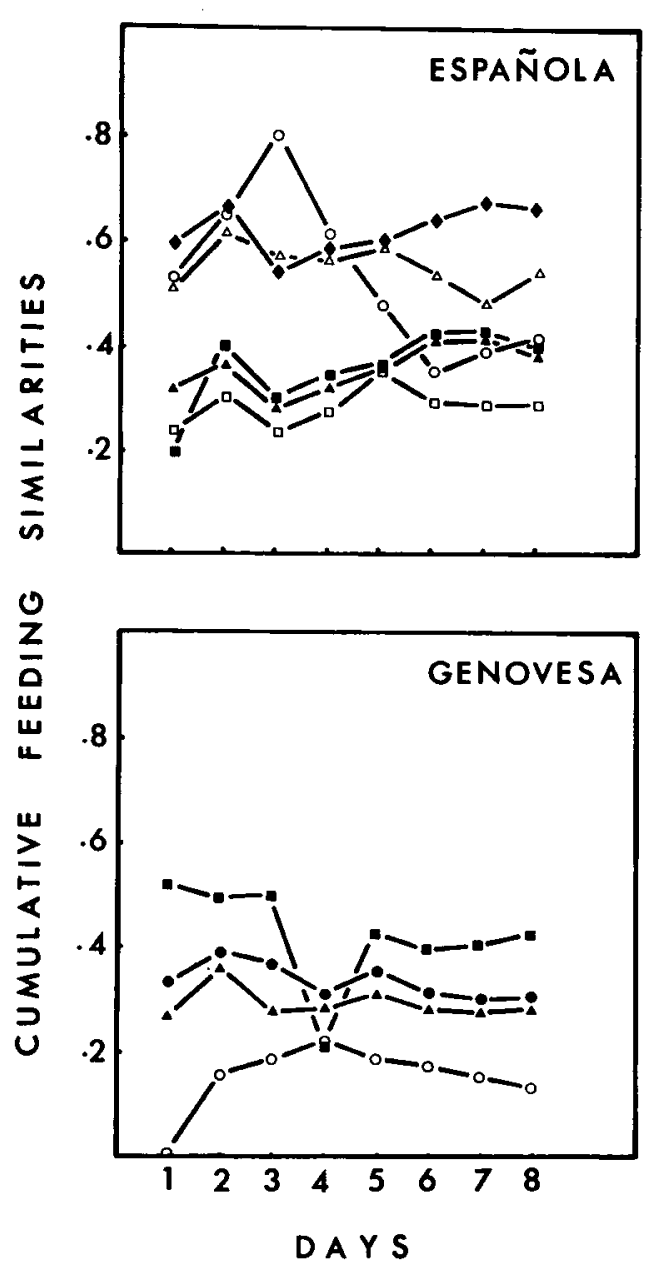

FIG. 3. Similarities in feeding niches between species, calculated from observations made on day 1 , day $1+2$, day $1+2+-+n$ over 8-day periods. Similarities are between $G$. conirostris on $\mathbf{I}$. Española (above) or I. Genovesa (below) and the following: G. magnirostris (O), G. fortis (A), G. scandens ( $\square), G$. conirostris on I. Genovesa $(\square), G$. fortis and $G$. scandens combined $(\Theta), G$. magnirostris and $G$. conirostris combined $(\triangle)$ and $G$. magnirostris, $G$. fortis and $G$. scandens combined $(\bullet)$. G. conirostris on I. Española is most similar to $G$. magnirostris, $G$. fortis and $G$. scandens combined, but $G$. conirostris on I. Genovesa is most similar to $G$. scandens alone.

fortis and scandens niche. Note too in Table 6 that the niche of Genovesa conirostris is not particularly broad or diverse.

\section{Comparison of Sympatric Feeding Niches}

The hypothesis of a competitive displacement of magnirostris and conirostris
TABLE 6. Measurements of feeding diversity $1 / \sqrt{\Sigma} \mathrm{p}_{t}^{2}$ and niche breadth $\overline{\mathrm{H}} / \mathrm{H}_{\text {max }}$ of Geospiza species. These are alternative measures of the variation in feeding characteristics of each species. $\mathrm{p}_{\mathrm{i}}$ is the proportion of feeding time spent on the ith food item. $\overline{\mathrm{H}}=-\Sigma \mathrm{p}_{\mathrm{i}}$ $\log _{10} \mathrm{p}_{\mathrm{i}}$ and $\mathrm{H}_{\max }=\log _{10} \mathrm{~S}$ where $\mathrm{S}=$ the number of food items taken. Data are from Table 4.

\begin{tabular}{lcc}
\hline \hline & $\begin{array}{c}\text { Feeding } \\
\text { diversity }\end{array}$ & $\begin{array}{c}\text { Niche } \\
\text { breadth }\end{array}$ \\
\hline Española conirostris & 3.96 & 0.90 \\
Daphne fortis & 3.20 & 0.63 \\
Genovesa conirostris & 3.19 & 0.68 \\
Daphne scandens & 3.14 & 0.61 \\
Genovesa magnirostris & 1.33 & 0.32 \\
\hline
\end{tabular}

on I. Genovesa predicts a low similarity in feeding niches between these two species. It also predicts that the two conirostris populations differ in their feeding niches in such a way that magnirostris feeds on items taken by conirostris on Española but not by conirostris on Genovesa.

Our results (Table 5) support these predictions. There is a particularly low similarity between magnirostris and conirostris on Genovesa, lower than any other pair of species compared. The similarity between the two conirostris populations is also low, but when Española conirostris is compared to a composite of Genovesa conirostris and magnirostris the similarity rises to .53. Reference to Table 4 shows the reason for these results. The low similarity between magnirostris and Genovesa conirostris is due to magnirostris feeding almost entirely on large-hard seeds, whereas conirostris exploits Opuntia parts and arthropods. The two populations of conirostris differ in four ways. The first is a discrete difference. Española conirostris feeds on large hard seeds, Genovesa conirostris does not. The three other differences are ones of degree. Opuntia helleri arils on Genovesa are succulent and abundant, and are taken more frequently than are the comparatively dry and fibrous arils of $O$. megasperma on Española. Also on Genovesa the tip-biting, twisting, tearing motion employed to strip bark off trees to reach arthropods is more highly developed, and occurs more frequently, than on Española. This is a habit employed fre- 
TABLE 7. Measurements in millimeters of random, cracked and rejected Cordia lutea seeds on I. Española and I. Genovesa.

\begin{tabular}{|c|c|c|c|c|c|c|c|}
\hline \multirow[b]{2}{*}{ Island } & \multirow[b]{2}{*}{ Sample } & \multicolumn{2}{|c|}{ Length } & \multicolumn{2}{|c|}{ Depth } & \multicolumn{2}{|c|}{ Length $\times$ depth } \\
\hline & & $N$ & $\bar{x} \pm \mathrm{SE}$ & $N$ & $\bar{x} \pm \mathrm{SE}$ & $N$ & $\bar{x} \pm \mathrm{SE}$ \\
\hline \multirow[t]{3}{*}{ Española } & Random & 106 & $10.3 \pm 0.1$ & 106 & $6.1 \pm 0.1$ & 106 & $63.2 \pm 1.4$ \\
\hline & Cracked by & & & & & & \\
\hline & G. conirostris & 108 & $8.8 \pm 0.1$ & 108 & $5.3 \pm 0.1$ & 108 & $46.5 \pm 1.0$ \\
\hline \multirow[t]{4}{*}{ Genovesa } & Random & 59 & $10.4 \pm 0.2$ & 59 & $6.8 \pm 0.1$ & 59 & $71.5 \pm 1.9$ \\
\hline & Cracked by & & & & & & \\
\hline & $\begin{array}{l}\text { G. magnirostris } \\
\text { Rejected by }\end{array}$ & 54 & $9.6 \pm 0.2$ & 54 & $6.3 \pm 0.1$ & 54 & $59.9 \pm 1.9$ \\
\hline & G. magnirostris & 22 & $9.7 \pm 0.3$ & 22 & $6.3 \pm 0.2$ & 22 & $61.6 \pm 2.8$ \\
\hline
\end{tabular}

quently by a tree finch with a similar beak size and shape, Camarhynchus psittacula, on other islands such as Pinta, Marchena and Santa Cruz (unpubl. observ.). Finally Opuntia pad ripping was rare on Genovesa in July yet quite common on Espanola in August. However it was common on Genovesa in November, (Grant and Grant, 1979; Grant and Grant, 1980a). In this instance, the difference between the niches of the two populations may be a little exaggerated because niches change seasonally and our observations on the two islands were not made at exactly the same time of the year.

\section{Food Selection and Feeding Efficiency}

To test the prediction that missing species would be less efficient than species present in dealing with foods, we concentrated on the feeding of adults of Española conirostris and Genovesa magnirostris upon a common food type, the seeds of Cordia lutea. Cordia lutea seeds were chosen because the stones or pits that contain them (Wiggins and Porter, 1971) are the largest and hardest of the fruits and seeds taken both by conirostris on Española and magnirostris on Genovesa. They are a major dry season food item in the diets of both species and for this reason, and because they are large and hard, they are most likely to reveal any difference in feeding efficiency between the two species (Grant et al., 1976). We collected and measured random samples of stones from the ground, the remains of all cracked stones found which were intact enough to permit measurement and, on Genovesa, all stones seen to be picked up and rejected without cracking by magnirostris. Table 7 gives the measurements, and Table 8 gives the results of statistical comparisons.

Cordia stones are larger on Genovesa than on Española, but on both islands birds tend to select the small stones. $\mathrm{Ge}$ ospiza magnirostris rejected stones of the same size as the ones they cracked, therefore the basis of rejection in this small sample must have been something other than size. Many of the stones seen to be rejected had emergence holes of a bruchid beetle, Amblycerus galapagoensis so this was possibly the reason for rejection. Eighty-five percent of the random sample of Cordia stones on Genovesa had larvae of this beetle; the larvae are eaten by magnirostris (and also by conirostris on Española). The rejected stones without emergence holes were not particularly large. Therefore the difference in size between stones cracked and stones at large reflects a selection by the finches that does not involve handling. In this case size is probably the cue used.

How would magnirostris perform on Española? The average size (length $X$ depth) of Cordia stones cracked by magnirostris on Genovesa is not significantly different from the average size of stones on Española $\left(t_{158}=1.10, P>.1\right)$. Therefore magnirostris would probably not be size-selective on Española. In contrast to this result, if Española conirostris were present on Genovesa it would be able to crack only the smallest Cordia stones, as indicated by a comparison of a random 
TABLE 8. Differences between samples of Cordia lutea tested by t tests. One to three asterisks indicate statistical significance $(<.05,<.01$ and $<.001$, respectively). Log-transformed data were used to test for a difference between random and cracked seeds on Española (length $\times$ depth) because variances were unequal.

\begin{tabular}{|c|c|c|c|c|c|c|c|}
\hline \multirow[b]{2}{*}{ Island } & \multirow[b]{2}{*}{ Sample } & \multicolumn{2}{|c|}{ Length } & \multicolumn{2}{|c|}{ Depth } & \multicolumn{2}{|c|}{ Length $\times$ depth } \\
\hline & & d.f. & $t$ & d.f. & $t$ & $d . f$. & d.f. \\
\hline Española & $\begin{array}{l}\text { Random vs. cracked } \\
\text { by } G \text {. conirostris }\end{array}$ & 188 & $7.00 * * *$ & 141 & $3.21 * *$ & 21.2 & $9.99 * * *$ \\
\hline Genovesa & $\begin{array}{l}\text { Random vs. cracked } \\
\text { by G. magnirostris }\end{array}$ & 111 & $3.81 * * *$ & 111 & $3.43^{* * *}$ & 81 & $5.79 * * *$ \\
\hline Genovesa & $\begin{array}{l}\text { Random vs. rejected } \\
\text { by } G \text {. magnirostris }\end{array}$ & 79 & $2.41^{*}$ & 79 & $2.51^{*}$ & 79 & $2.84 * *$ \\
\hline Genovesa & $\begin{array}{l}\text { Cracked by } G . \text { magni- } \\
\text { rostris vs. rejected } \\
\text { by } G . \text { magnirostris }\end{array}$ & 74 & 0.35 & 74 & 0.08 & 74 & 0.30 \\
\hline $\begin{array}{c}\text { Española vs. } \\
\text { Genovesa }\end{array}$ & Random & 163 & 0.48 & 163 & $5.67 * * *$ & 163 & $3.44 * * *$ \\
\hline $\begin{array}{c}\text { Espanola vs. } \\
\text { Genovesa }\end{array}$ & Cracked & 160 & $4.31 * * *$ & 89 & $4.57 * * *$ & 160 & $7.97 * * *$ \\
\hline
\end{tabular}

sample of stones from Genovesa and the sample cracked by conirostris on Espanola $\left(t_{160}=7.97, P<.001\right)$. This is further illustrated in Figure 4. It is not surprising, in view of this result, that the small-billed form of conirostris which does occur on Genovesa (Fig. 2) does not crack stones of Cordia lutea.

Not only do magnirostris on Genovesa take larger Cordia stones than conirostris on Española, they take much less time on average to crack them $(13.6 \pm 2.6 \mathrm{~s}$, $N=36)$ than conirostris on Española (24.2 $\left.\pm 3.3 \mathrm{~s}, N=45 ; t_{79}=3.25, P<.001\right)$. However the total handling time on Cordia stones is not significantly different $(P>.1)$ between conirostris $(89.7 \pm 10.3$ s, $N=45)$ and magnirostris (71.6 \pm 6.5 s, $N=44$ ). Total handling time refers to the period of time between picking up a stone and finishing feeding on the seed or beetle larva. We did not include searching time and we did not detect any difference in the time taken to extract seeds and larvae. Overall the total efficiency of Cordia seed exploitation is approximately the same in the two species, in terms of energy intake per unit of energy expended.

A very small difference in metabolism between the species is suggested by the small difference in body weights in Table 1. Thus if magnirostris was on Española it would have slightly higher energetic costs through being slightly larger. But this disadvantage would probably be more than offset by two feeding advantages; it would presumably handle the small Cordia stones slightly faster than conirostris, and it would be able to deal quickly with the large Cordia stones which conirostris has difficulty in cracking or else avoids. Small differences in metabolism would only be important if, in addition, magnirostris were much poorer at finding Cordia stones than conirostris, in which case energetic costs of searching would be much higher in magnirostris than conirostris.

Figure 5 shows that the advantage possessed by magnirostris over conirostris in cracking Cordia stones is held, although to a lesser extent, with smaller and softer seeds. In this figure, the average time each species takes to crack a seed is seen to rise with an increase in seed size and hardness. Unfortunately the number of points for each finch species is too small for analysis by regression, and pairwise comparisons of finch species are limited by the small number of seeds of a given type eaten by two species. The main point we wish to make is that there is no detectable reversal of the relative efficiencies of magnirostris and conirostris towards the lower end of the seed size-hardness scale. A graph of 

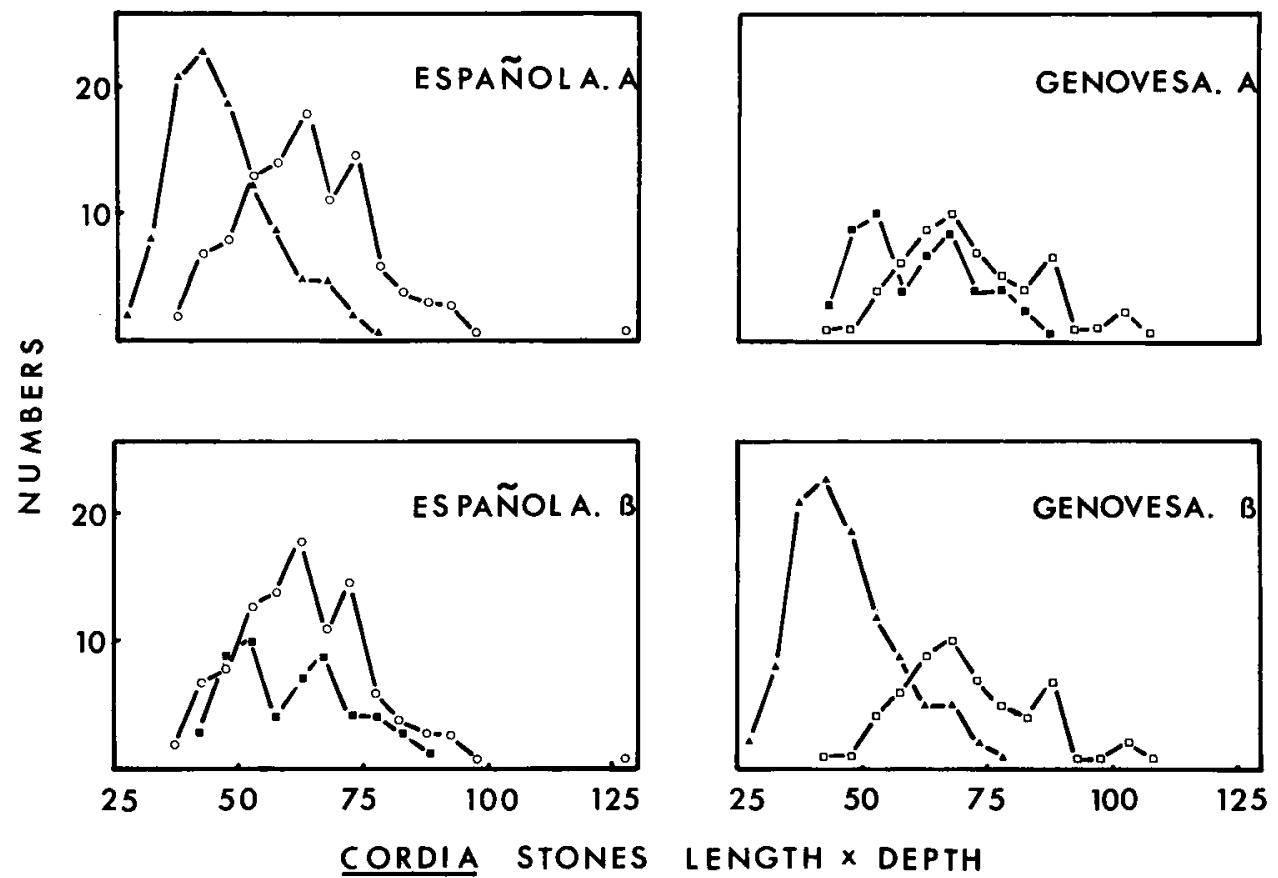

FIG. 4. Frequency distributions of the sizes of Cordia lutea stones measured in two dimensions in millimeters. On I. Española the stones sampled at random $(O)$ are compared with those cracked by $G$. conirostris $(\boldsymbol{A})$ in $A$, and with the superimposed distribution of seeds cracked by $G$. magnirostris $(\square)$ on $I$. Genovesa in B. On I. Genovesa the stones sampled at random ( $\square$ ) are compared with those cracked by $G$. magnirostris $(\boldsymbol{\square})$ in A and with those cracked by $G$. conirostris $(\boldsymbol{\Delta})$ on I. Española in B.

seed handling times plotted against seed size-hardness gives the same results.

Figure 5 also shows that conirostris has a feeding efficiency advantage over fortis (without taking metabolic requirements into account). Thus the prediction of the competition hypothesis that conirostris has a feeding efficiency advantage over fortis is found to be correct, but the prediction that conirostris has a feeding efficiency advantage over magnirostris was not supported by our results; rather magnirostris appears to have an advantage over Española conirostris. A necessary qualification is that if immigrant magnirostris were immatures, they might be at a feeding efficiency disadvantage in relation to adult conirostris, because on Genovesa immature magnirostris take significantly longer to crack Cordia stones $(36.9 \pm 8.15$, $N=4)$ than do adult magnirostris $\left(t_{38}=3.83, P<.001\right)$.

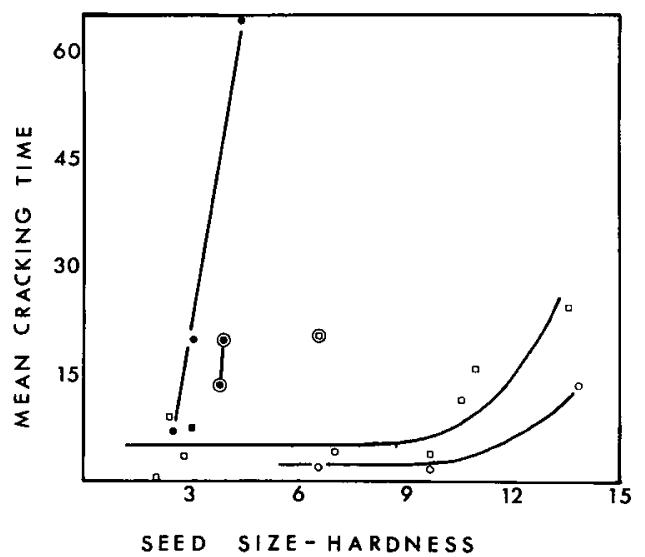

FIG. 5. The average time in seconds to crack seeds and fruits of several plant species as a function of the size and hardness of those seeds as indexed by the square root of the depth in millimeters $x$ the hardness in kgf. The finch species are $G$. magnirostris from I. Genovesa (O), G. scandens from I. Daphne (D), G. fortis from I. Daphne (O) and from I. Santa Cruz (O) where it is larger (Grant et al. , 1975), and G. conirostris from I. Española ( $\square$ ) and from I. Genovesa (@). Curves have been fitted by eye. 


\section{Discussion}

The interspecific competition hypothesis has been supported by several but not all of our observations. Our ecological data support Lack's hypotheses that fortis and scandens have been competitively excluded from Española by conirostris; that scandens has been competitively excluded from Genovesa by conirostris; and that competitive character displacement between conirostris and magnirostris could have occurred on Genovesa. The evidence does not support the view that fortis has been excluded by conirostris from Genovesa, or that magnirostris has been excluded by conirostris from Española. We will first discuss the main assumptions upon which these conclusions rest, then consider alternative explanations for our results and finish by pointing out two implications of our study.

We have assumed that an equal weighting of niches is appropriate for the comparison of conirostris niches with the combined niches of missing species. An unequal weighting may be more realistic, perhaps based upon degree of bill size and shape similarities, but this would not alter the results strongly. Second, we have assumed that the results are not substantially affected by the particular allopatric populations used in comparisons with conirostris. This assumption is especially important in our use of magnirostris data, since those data come from an island where one population of conirostris is present. Our magnirostris data from Genovesa in July (this study) and November (Grant and Grant, 1980a) are similar to magnirostris data from I. Pinta and I. Marchena (D. Schluter, pers. comm.) and I. Santa Cruz (Smith et al., 1978) in showing that large and hard seeds predominate in dry season diets. Beak sizes of magnirostris on these islands are similar (see Lack, 1947). Therefore we believe this assumption is approximately correct.

Third, we have assumed that the results are not dependent upon which year we studied the finches. Since year-to-year variation in rainfall, plant production and seed availability can produce annual shifts in feeding niches (Grant and Grant, 1980b), our results may be partly dependent on the relatively plentiful food supply in the years of our study. We have tried to eliminate this bias as much as possible by restricting our comparisons to years when there was comparable rainfall in the preceding wet season on all study islands. Rainfall in 1975 was above average on Daphne (Grant and Boag, 1980), and in 1979 about average on Genovesa and Española. But even in years of substantial rainfall, food supply limits population sizes during the dry season (Smith et al., 1978). In dry years this limiting influence is especially strong (Boag and Grant, 1981). It would be preferable to make inter-island comparisons in a dry year, but the only data we have from a dry year comes from Daphne (Grant and Grant, 1980b; Boag, 1981; Boag and Grant, 1981).

A fourth assumption is that other potential biotic factors not considered, such as disease and predation, can be ignored. Very little is known about disease, and nothing is known to suggest that it would be an important factor on one island and not on another. The three main predators are the Galápagos hawk Buteo galapagoensis (deVries, 1976), and the short-eared owl Asio flammeus (Grant et al., 1975; Grant and Grant, 1980a) and mockingbirds Nesomimus spp. (Downhower, 1978; Grant and Grant, 1980a). The owl is present on all our study islands, mockingbirds are present on both Española and Genovesa, but the hawk is present on only Española. From this it could be argued that magnirostris is predator-excluded from Española, but this would be inconsistent with the coexistence of magnirostris and hawks on other islands (Lack, 1947; Harris, 1973), and would presumably require a preferential predation upon magnirostris for reasons of its slightly larger size or its rarity.

A fifth assumption is that the inferred competition is with the specified species and not with others. This may be incorrect. Since Lack's (1969) last treatment of the subject, MacArthur (1972) and 
MacArthur et al. (1972) have drawn attention to the competitive influence of many species upon one, and introduced the term diffuse competition to describe it. In the present context magnirostris, fortis and scandens may be absent from Española for reasons of competition with conirostris, fuliginosa, Nesomimus macdonaldi (mockingbird) and Zenaida galapagoensis (dove). Likewise the absence of scandens and fortis from Genovesa may be due to the combined influence of magnirostris, conirostris, difficilis, Nesomimus parvulus and Zenaida galapagoensis or some combination of these species (e.g., conirostris and magnirostris: Lack, 1969). All eat seeds and Opuntia parts, and all show a divergence in diets from wet season to dry season which suggests an avoidance of competition (Grant and Grant, 1980a). The remaining land bird species on these islands, Certhidea olivacea, Dendroica petechia and Myiarchus magnirostris (Española only), can be ignored because they have diets of arthropods and are therefore not likely to compete with the others.

The data in Tables 2 and 3, combined with data in Abbott et al. (1977), Smith et al. (1978) and Grant and Grant (1980a), make the possibility of diffuse competition plausible, because they show that some foods taken frequently by fortis elsewhere are taken frequently by fuliginosa on Española and by difficilis on Genovesa; Lack (1969) ignored these two species in his analyses. The hypothesis of diffuse competition is extremely difficult to test (Abbott and Grant, 1976), nevertheless we must acknowledge that it could succeed in explaining the absence of fortis from Genovesa where the hypothesis of competition with conirostris fails.

Finally we have assumed that changes in the vegetation of Española caused by goats introduced in the last century have not created a bias in our comparisons with the undisturbed islands of Daphne and Genovesa. Such a bias could arise if current conirostris morphology and feeding were adapted more to past pre-disturbance conditions on Española than to modern post-disturbance conditions. However, the argument that bills of contemporary conirostris are adapted to past conditions is difficult to sustain in the face of evidence of rapid morphological change in a population of fortis under selection for large bill size (Boag and Grant, 1981). If the altered vegetation resulted in a change in conirostris phenotype it probably occurred in the last century: we have been unable to detect a change this century in comparisons between specimens collected in 1905-06 and modern ones.

Even though the competition hypothesis has been largely supported by the results of the tests and its assumptions are reasonable, other hypotheses may be just as good or better. We now consider three other hypotheses.

The first alternative is that species are absent from an island because their food niches are absent. For example, Bowman (1961 p. 286) wrote "the nature of the vegetation on Hood Island [Española] is such that possibly there are too few hardcoated seeds to support a population of $G$. magnirostris, and too few Opuntia cactus plants to support G. scandens." Presumably this explanation can be extended to account for the absence of fortis as well. The hypothesis was tested in our study and found to be incorrect. These species are not absent from Española because of the absence of an appropriate food supply, nor are fortis and scandens absent from Genovesa for that reason.

The food supply hypothesis has been invoked by Bowman (1961) to explain differences in feeding niches a) between coexisting species, such as conirostris and magnirostris on Genovesa, and b) between populations of the same species on different islands, such as conirostris on Genovesa and Española. It is succinctly stated as follows: "Anatomical differences between closely related species on any one island are best thought of as biological adjustments which have been evolved when the forms were in isolation. These adjustments could have prevented 'competition' from occurring between the forms when subsequently they came together on the 
same island" (Bowman, 1961 p. 296). Therefore, conirostris populations differ in beak morphology and diets because they have become adapted to the different food supplies the islands possess, and coexisting conirostris and magnirostris populations on Genovesa differ because their adaptations occurred originally on different islands.

This hypothesis, like the competition hypothesis, rests on the assumption that diet and beak shape are correlated, hence feeding niches are correctly inferred from beak morphology. Bowman (1961) presented empirical evidence to support this assumption as it applies to differences between coexisting species, but not as it applies to inter-island differences within species. The food supply hypothesis has the additional merit of constituting a null alternative (no interaction) to the competition hypothesis (Abbott et al., 1977; Strong et al., 1979; Grant and Abbott; 1980). It has two serious problems, however, that make it useful only to the extent that other hypotheses fail.

The first problem is that it is doubtful if there are enough islands in the archipelago for all sympatric populations to have evolved their adaptations for food gathering in isolation from each other, i.e., allopatrically. This makes the hypothesis unreasonable in its more general, all-embracing form, but it could still be correct in specific instances. The second problem is that it explains the absence of a species from an island by the absence of the appropriate food supply, yet it allows for adaptation of new colonists to a local food supply which differs from the supply on the island of origin. With such comprehensiveness it is close to being unfalsifiable. The dividing line between conditions that preclude establishment of colonists and conditions that allow establishment and persistence long enough for adaptation to take place needs to be specified, but it would be extremely difficult to do so operationally (see also Grant, 1975). Because of these difficulties we placed greater emphasis in this paper on testing the competition hypothesis. Results of the test generally supported the competition hypothesis, and we have no reason to turn to the operationally more complex food hypothesis to explain morphology and distribution of the finches.

A second explanation for the absence of fortis and scandens from both islands and magnirostris from Española is that they have not been able to reach these islands. These two islands may be relatively inaccessible to birds by virtue of their positions in relation to neighboring islands (see Fig. 1) and prevailing winds (Power, 1975). This explanation for species absences has been repeatedly rejected on the grounds that inter-island wanderings are quite frequent (Lack, 1947, 1969; Bowman, 1961; Harris, 1973). For example, 15 fortis individuals were collected on Española in 1906, and I. Abbott (pers. comm.) observed one in June 1973. One individual has been collected on Genovesa, and we observed two there in July 1979 (see also Yang and Patton, 1981). We also netted an adult male scandens on Genovesa at the same time and one individual has been collected 20 miles from the nearest island (Gifford, 1919). Geospiza magnirostris also make inter-island movements (Grant et al., 1975).

A third hypothesis for the absence of breeding populations of species on Espanola and Genovesa is that the few individuals who reach the islands and survive to the breeding season fail to find conspecific mates and hybridize with members of one of the resident species. We refer to this as the immigrant-hybridization hypothesis. For example, it is plausible that small numbers of magnirostris hybridizing with conirostris have been partially responsible for the more magnirostris-like features in the Española conirostris bill. We do not know if hybrid offspring would be viable, but viability is likely because two magnirostris $\times$ conirostris pairs produced viable offspring on Genovesa in 1980 and 1981 (unpubl. observ.). A parallel situation occurs on Daphne. Geospiza fuliginosa has repeatedly immigrated since our study began there in 1973. It has not established a breeding population but a few individuals 
have hybridized with the resident larger species G. fortis (Boag, 1981; Grant and Price, 1981). Geospiza fortis are unusually small on this island.

Hybridization might also occur between two species if one becomes rare: the few individuals of the rare species then court heterospecifics in the virtual absence of conspecifics. An unbalanced sex ratio in the common species (cf. Boag and Grant, 1981) could facilitate the acceptance of heterospecific mates. We refer to this alternative as the resident-hybridization hypothesis. It may be invoked to explain the absence of magnirostris from Española by supposing that magnirostris was once present and common, became rare, hybridized with conirostris and disappeared as a species.

Some support for the hypothesis is provided by the particularly large form of magnirostris on the neighboring islands of Santa María and S. Cristóbal. It was once common but became extinct on both islands sometime after Darwin's visit in 1835 (Steadman, 1981; Sulloway, 1982). A few museum specimens of intermediate size from these two islands (e.g., see Sulloway, 1982) suggest that magnirostris and fortis hybridized during the period of decline of the magnirostris populations. By the time Española was first visited by collectors at the end of the nineteenth century, magnirostris was already extinct (or exceedingly rare) on the other two islands. If it had been present earlier on Española as well, it would have been larger than conirostris in bill dimensions by much more than $15 \%$, which is the minimum difference between currently coexisting species in the archipelago (Grant, 1981b). Even the smaller form of magnirostris on Santa Cruz is larger than conirostris in bill depth by more than $15 \%$.

Why did the two, possible three, populations of magnirostris go extinct? The large bill may have been adapted to cracking the particularly large and hard seeds of Opuntia megasperma. This species of Opuntia has the largest and hardest seeds of any Opuntia species in the archipelago; the size-hardness index is 10.9 on Espa- ñola and more than 20 on Champion (unpubl. data) in contrast to a range of 2 to 7 for the other species (Grant and Grant, 1981). The species is present on only the three southern islands and their satellites. Populations of Opuntia were decimated in this century and the last one by human destruction of natural habitat on Santa María and S. Cristóbal, and by introduced goats on all three islands. Nowadays, $O$. megasperma only grows in large stands on the goat-free islets of Champion and Gardner off Santa María. Thus direct and indirect effects of human activity probably caused the demise of the magnirostris populations, although we have no detailed knowledge of why they were not sustained by alternative foods such as the seeds of Cordia lutea and Prosopis juliflora.

The changes occurring on the southern islands in both habitat and finch populations in the last 150 years have been so poorly documented that most of these ideas about past hybridization will remain as speculation. The hypothesis will be supported, however, if fossils of magnirostris and of intermediates with conirostris are found on Española; fossils of magnirostris have recently been found on Santa María (Steadman, 1981). The immigrant-hybridization hypothesis can be investigated directly, at least in principle. However, magnirostris was not recorded on Española by collectors at the turn of the century (e.g., Gifford, 1919), or in recent field studies (Abbott et al., 1977; Downhower, 1978; this study). The role of hybridization in the evolution and distribution of the finches remains an open question.

We conclude by making a general point that emerges from this discussion. Biogeographic analyses have made an important contribution already by showing how widespread competitive effects might be (Lack, 1947, 1976; Diamond, 1972, 1975; MacArthur, 1972; Brown, 1975; for criticism see Connor and Simberloff, 1978, 1979; Simberloff, 1978; Strong et al., 1979), but we believe that because interspecific competition is an ecological process, ecological studies are required to test the hypothesis. The present study has provided 
some ecological tests but it has also identified areas of ignorance that deserve attention not only among Darwin's Finches but in all similar studies of island communities.

The first is the colonization of islands or, to be more general, the entry of new species into a community. In the case of Darwin's Finches, most inter-island wanderers are first-year birds. As many as $\mathbf{1 0 0}$ or more may arrive on an island following one breeding season, and invariably all leave (or die) before or during the next breeding season (Grant et al., 1975; unpubl. observ. on I. Daphne). They do not have sub-normal weights, and with few exceptions they do not exhibit reproductive behavior if they stay up to the beginning of the breeding season. Factors other than interspecific competition for food are likely to influence the decisions of individuals to stay or to leave. These factors presumably include those which stimulate reproductive activity, and the possible tendencies of birds to return to their natal area or nearby to breed. Therefore ease of dispersal from one island to another, which seems to be indicated by the known immigrations, should not be equated with ease of establishing a breeding population (Grant, 1977). In particular, the absence of magnirostris from Española may have more to do with conditions suitable for starting a breeding population than with dispersal to the island, food supply or competition (see also Abbott, 1978, 1980).

The second area of ignorance is the process of competition over long periods of time. We have shown how annual variation in rainfall alters plant production and produces substantial changes in feeding niches between years (Grant and Grant, $1980 b$ ). We have also seen large changes between years in the numerical proportions of conirostris and magnirostris on Genovesa and fortis and scandens on Daphne (Grant and Grant, 1980b). There may have been a fluctuating competitive balance between conirostris and magnirostris on Española, leading to the extinction of the latter perhaps during a series of dry years when Cordia and Prosopis seeds were rare and conirostris were able to subsist on arthropods found in Opuntia pads and beneath bark. Extinctions are not likely to be observed, but they can be inferred from extrapolations of observed fluctuations. To understand the absence of species on islands and the ecological and morphological differences between those present, there is no real substitute for direct studies of food availability and use by coexisting species over a long period of time (Wiens, 1977; Smith et al., 1978; Abbott, 1980; Grant and Grant, 1980b).

\section{SUMMARY}

This study tested predictions of the competition hypothesis which Lack (1945, 1969) applied to Darwin's Finches on the Galápagos islands in order to explain their adaptive radiation. Lack suggested that Geospiza conirostris has competitively excluded $G$. fortis and $G$. scandens from I. Espanola and I. Genovesa and G. magnirostris from I. Española; and further that $G$. conirostris populations exhibit competitive displacement (Genovesa), competitive release (Española), or both. We tested four predictions of this hypothesis using quantitative ecological data and obtained mixed results.

(1) The prediction that Española conirostris has a broad feeding niche which is more similar to a combined magnirostrisfortis-scandens niche than to the niches of these species considered separately was upheld. The niche of Española conirostris is unusually broad.

(2) The prediction that Genovesa conirostris had a feeding niche similar to a combined fortis-scandens niche was not upheld. The niche of Genovesa conirostris is more similar to the niche of scandens alone.

(3) The prediction that conirostris and magnirostris have dissimilar niches on Genovesa, and that the difference lies in magnirostris taking food items exploited by conirostris on Española but not on Genovesa, was verified.

(4) The prediction that conirostris on Española was more efficient than magnirostris at dealing with foods on that island 
was not upheld, although conirostris on both islands were more efficient than fortis and scandens.

We conclude that interspecific competition has influenced the distribution and morphology of Darwin's Finches, but our results do not support the hypothesis of competitive exclusion in two particular cases; the exclusion of fortis from Genovesa and magnirostris from Española by conirostris. We cannot explain the absence of fortis and magnirostris from the two islands by the lack of suitable foods or by the failure of the species to reach these islands. Geospiza fortis may be absent because of a combined (diffuse) competitive effect of magnirostris, conirostris and difficilis. A breeding population of magnirostris may be lacking on Española because whenever magnirostris arrive, in small numbers, they die, depart or hybridize with conirostris. The only condition under which competitive exclusion is likely is the immigration of immature magnirostris, because immature birds are likely to be less efficient at dealing with hard seeds than adult resident conirostris.

Two areas of ignorance in need of empirical investigation are discussed. The first is the set of conditions that determine the establishment of a breeding population on an island; food supply and competition are not the sole factors. The second is the extent of competition for food in a temporally fluctuating environment.

\section{ACKNOWLEDGMENTS}

This research carried out with the permission of the Direccion General de Desarrollo Forestal, Quito, Ecuador, the Charles Darwin Foundation and the Charles Darwin Research Station. It was supported by grants from NRC Canada (A2920) and NSF (DEB79-21119). We thank P. T. Boag, K. T. Grant and N. Grant for field assistance, I. Abbott for permission to use his measurements of birds, and I. Abbott, J. Myers, T. D. Price, J. T. Rotenberry, D. Schluter, J. N. M. Smith and a referee for valuable comments on a manuscript. Order of author- ship was determined by the toss of a sexbiased coin.

\section{Literature Cited}

Aввотт, I. 1978. Factors determining the number of land bird species on islands around SouthWestern Australia. Oecologia 33:221-233.

— 1980. Theories dealing with the ecology of land birds on islands. Adv. Ecol. Res. 11:329-371.

AввotT, I., L. K. AвbotT, ANd P. R. GRANT. 1977. Comparative ecology of Galápagos Ground Finches (Geospiza Gould): evaluation of the importance of floristic diversity and interspecific competition. Ecol. Monogr. 47:151-184.

Аввотт, I., AND P. R. GRANT. 1976. Non-equilibrial bird faunas on islands. Amer. Natur. 100:507-528.

Arms, K., and P. S. Camp. 1979. Biology. Holt, Rinehart and Winston, N.Y.

BOAG, P. T. 1981. Morphological variation in the Darwin Finches (Geospizinae) of Daphne Major Island, Galápagos. Ph.D. Thesis. McGill Univ.

BoAG, P. T., AND P. R. GRANT. 1981. Intense natural selection on a population of Darwin's Finches (Geospizinae) in the Galápagos. Science 214:82-85.

Bowman, R. I. 1961. Morphological differentiation and adaptation in the Galápagos finches. Univ. Calif. Publ. Zool. 58:1-302.

- 1979. Adaptive morphology of song dialects in Darwin's Finches. J. Ornithol. 120:353-389.

BRowN, J. H. 1975. Geographical ecology of desert rodents, p. 315-341. In M. L. Cody and J. M. Diamond (eds.), Ecology and Evolution of Communities. Harvard Univ. Press, Cambridge.

CoLwell, R. K. 1979. Toward a unified approach to the study of species diversity, p. 75-91. In J. F. Grassle, G. P. Patil, W. Smith, and C. Taillie (eds.), Ecological Diversity in Theory and Practice. International Co-operative Publ. House, Fairland, Maryland.

Colwell, R. K., AND D. J. Futuyma. 1971. On the measurement of niche breadth and overlap. Ecology 52:567-576.

ConNell, J. H. 1975. Some mechanisms producing structure in natural communities: a model and evidence from field experiments, p. 460-490. In M. L. Cody and J. M. Diamond (eds.), Ecology and Evolution of Communities. Harvard Univ. Press, Cambridge.

- 1978. Diversity in tropical rain forests and coral reefs. Science 199:1302-1310.

- 1980. Diversity and the coevolution of competitors, or the ghost of competition past. Oikos 35:131-138.

Connor, E. F., ANd D. S. Simberloff. 1978. Species number and compositional similarity of the Galápagos flora and avifauna. Ecol. Monogr. 48:219-248.

- 1979. The assembly of species communities: chance or competition? Ecology 60:1132-1140. 
DEVRIEs, TJ. 1976. Prey selection and hunting methods of the Galápagos Hawk, Buteo galapagoensis. Le Gerfaut 66:3-42.

DiAMOND, J. M. 1972. Avifaunal equilibria and species turnover rates on the Channel Islands of California. Proc. Nat. Acad. Sci. USA 64:57-63.

-1 1975. Assembly of species communities, p. 342-444. In M. L. Cody and J. M. Diamond (eds.), Ecology and Evolution of Communities. Harvard Univ. Press, Cambridge.

DownHOWER, J. F. 1978. Observations on the nesting of the small ground finch Geospiza fuliginosa and the large cactus ground finch $G$. conirostris on Española, Galápagos. Ibis 120:340-347.

GiFFord, E. W. 1919. Field notes on the land birds of the Galápagos Islands and of Cocos Island, Costa Rica. Expedition of the California Academy of Sciences to the Galápagos Islands, 1905-1906. XIII. Proc. Calif. Acad. Sci., 4th Ser. 2, Pt. 2:189-258.

Grant', B. R., AND P. R. Grant. 1979. Darwin's finches: population variation and sympatric speciation. Proc. Nat. Acad. Sci. USA 76:2359-2363.

- 1981. Exploitation of Opuntia cactus by birds on the Galápagos. Oecologia 49:179-187.

GRANT, P. R. 1975. The classical case of character displacement. Evol. Biol. 8:237-337.

- 1977. Review of island biology, illustrated by the land birds of Jamaica. David Lack, 1976. Berkeley and Los Angeles, Univ. Calif. Press. Bird-Banding 48:296-300.

- 1981a. The feeding of Darwin's Finches on Tribulus cistoides (L.) seeds. Anim. Behav. 29:785-793.

- 1981b. The role of interspecific competition in the adaptive radiation of Darwin's Finches. In A. Levinton and R. I. Bowman (eds.), Patterns of Evolution in Galápagos Organisms. Special Publication, Amer. Asso. Adv. Sci., Pacific Division.

Grant, P. R., AND I. AввотT. 1980. Interspecific competition, island biogeography and null hypotheses. Evolution 34:332-341.

Grant, P. R., AND P. T. Boag. 1980. Rainfall on the Galápagos and the demography of Darwin's Finches. Auk 97:227-244.

Grant, P. R., and B. R. Grant. 1980a. The breeding and feeding characteristics of Darwin's Finches on Isla Genovesa, Galápagos. Ecol. Monogr. 50:381-410.

- $1980 b$. Annual variation in finch numbers, foraging and food supply on Isla Daphne Major, Galápagos. Oecologia 46:55-62.

Grant, P. R., B. R. Grant, J. N. M. Smith, I. J. AbBott, AND L. K. Aвbotr. 1976. Darwin's finches: population variation and natural selection. Proc. Nat. Acad. Sci. USA 73:257-261.

Grant, P. R., AND T. D. Price. 1981. Population variation in continuously varying traits as an ecological genetics problem. Amer. Zool. 21:00-00.

Grant, P. R., J. N. H. Smith, B. R. Grant, I. J. AвbotT, and L. K. Aвbott. 1975. Finch numbers, owl predation and plant dispersal on
Isla Daphne Major, Galápagos. Oecologia 19:239-257.

HARris, M. P. 1973. The Galápagos avifauna. Condor 75:265-278.

HuRLBerT, S. H. 1978. The measurement of niche overlap and some relatives. Ecology 59:67-77.

LACK, D. 1940. Evolution of the Galápagos finches. Nature 146:324-327.

- 1945. The Galápagos finches (Geospizinae): a study in variation. Occas. Pap. Calif. Acad. Sci. 21:1-159.

- 1947. Darwin's Finches. University Press, Cambridge.

-1969. Subspecies and sympatry in Darwin's Finches. Evolution 23:252-263.

1976. Island Biology, Illustrated by the Land Birds of Jamaica. Univ. Calif. Press, Berkeley and Los Angeles.

MacArthuR, R. H. 1972. Geographical Ecology. Harper and Rowe, N.Y.

MacArthur, R. H., J. M. Diamond, AND J. R. Karr. 1972. Density compensation in island faunas. Ecology 53:330-342.

PIANKA, E. R. 1969. Sympatry of desert lizards (Ctenotus) in Western Australia. Ecology 50:1013-1030.

Power, D. M. 1975. Similarity among avifaunas of the Galápagos Islands. Ecology 56:616-626.

RICHARDS, O. W. 1948. Species formation on islands. Review of D. Lack (1947). Darwin's finches, Cambridge Univ. Press. J. Anim. Ecol. 17:83-84.

Ricklefs, R. E., AND M. LAU. 1980. Bias and dispersion of overlap indices: results of some Monte Carlo simulations. Ecology 61:1019-1024.

Ricklefs, R. E., AND J. Travis. 1980. A morphological approach to the study of avian community organization. Auk 97:321-338.

Rotenberry, J. T., AND J. A. Wiens. 1980. Habitat structure, patchiness, and avian communities in North American steppe vegetation: a multivariate analysis. Ecology 61:1228-1250.

SIMBERLOFF, D. S. 1978 . Using island biogeographic distributions to determine if colonization is stochastic. Amer. Natur. 112:713-726.

Smith, J. N. M., P. R. Grant, B. R. Grant, I. J. AвBOTT, AND L. K. AввOTT. 1978. Seasonal variation in feeding habits of Darwin's Ground Finches. Ecology 59:1137-1150.

Streadman, D. W. 1981 . Vertebrate fossils in lava tubes in the Galápagos Islands. Proc. Eighth Internat. Congr. Speleology, Vol. I:549-550.

Strong, D. R., JR., L. A. SzySKa, AND D. S. Simberloff. 1979. Tests of community-wide charcter displacement against null hypotheses. Evolution 33:897-913.

Sulloway, F. J. 1982. The Beagle Collections of Darwin's Finches (Geospizinae). Bull. British Museum Nat. Hist., Zool. Ser.

WhitTaker, R. H. 1960 . Vegetation of the Siskiyou Mountains, Oregon and California. Ecol. Monogr. 30:279-338. 
WIENS, J. A. 1977. On competition and variable environments. Amer. Sci. 65:590-597.

Wiens, J. A., AND J. RotenberRy. 1980. Patterns of morphology and ecology in grassland and scrubsteppe bird populations. Ecol. Monogr. 50:287-308.

Wrggins, I. L., AND D. M. Porter. 1971. Flora of the Galápagos Islands. Stanford Univ. Press, Palo Alto.
Williamson, M. 1972. The Analysis of Biological Populations. Edward Arnold, London.

Yang, S. Y., AND J. L. Patton. 1981. Genic variability and differentiation in Galápagos finches. Auk 98:230-242.

Corresponding Editor: R. E. Ricklefs 